borers, arrow points, and tubes of bone. Fish bones, scarce at the beginning of this period, were found in large quantities in later levels, pointing to the development of a considerable competence in fishing. Banked ash at the southern end indicated a protection fireplace, dividing the cave shelter into two compartments, one for general purposes and one for sleeping.

Below the thirty-six inch level Smithfield $C$ material extends down to a depth of sixty inches, the richest level being between thirty-six and fifty-four inches. Throughout the deposit only implements of the general scraper type could be recognized with certainty. More than five thousand scrapers in white quartz were collected from the Smithfield deposit. There were as well two hundred flakes of brown chalcedony. The quartz flakes, almost a solid mass, in parts up to two feet in depth, indicated that the shelter at this period must have been a workshop. Throughout this deposit ostrich shell beads in large numbers were found, but nacre ornaments are rare.

At the base of the Smithfield $C$ deposit between two buffer layers was a carbon floor or layer, representing a period of peculiarly fierce forest fire, which was presumably the cause of the desertion of the cave by the Smithfield $B$ people. The Smithfield $B$ culture extended from a depth of sixty inches down to seventy-seven inches or more in parts. It is to be remarked that there is no great difference to be observed between the implements from above and below the carbon floor. The variation is rather one of size, or in distribution of sizes. The scrapers, for example, are much larger. All implements are still of the general scraper family. The deposit as a whole is far less rich than the Smithfield $C$ layer and represents the normal debris of a home site. The major part of the material is quartz, chalcedonic quartz being rare and brown chalcedony absent. One end scraper is of fossilized wood from the Tertiary Enon beds. A Mossel Bay point and a Still Bay type mark the overlying deposit as post-dating the "Cape Flats complex".

Below seventy-seven inches evidence of the sterile charaeter of the lower deposits begins to become apparent. In one section a few good Smithfield $B$ specimens still appear between the eighty-four and ninety inch levels; but below ninety-six inches formal implements disappear. In the underlying material there are only scattered hearths with burnt bones and quartz split by fire or broken by man, but no implement types that could be recognized. Though there are suggestions of Middle Stone Age technique on some of the flakes, these must be ignored, as deduction from the sugary quartz would be impossible to maintain. There is, however, evidence to show that use was made of the shelter for a very considerable period before Smithfield $B$ man appears.

The pottery has been submitted to a careful and detailed analysis by Mr. J. F. Schofield, who terms it "Hottentot", and suggests that its specific characters, lugs and an occasional oval section, are an adaptation to the use of the pack-ox by a nomadic people.

The skeletal material has been studied by Prof. M. R. Drennan, whose detailed report deals with the relation of the Oakhurst people to the Wilton race and the Hottentot. The skeletal material shows that these people had many Bushmen characters, but they were of a special type, being much taller and more robust, with bigger heads. They resembled the type to which the term 'Hottentot' has been applied-a term which accordingly has to be defined (see NATURE, p. 1146). The main conclusion is that the Boskop type must be regarded as the ancestor of the Hottentot. The infantile material, which is the first series of any extent to be examined systematically, has provided data for a study of growth in infancy.

\title{
Submarine Light Measurements
}

$\mathrm{A}^{\mathrm{T}}$ $T$ the meeting of the International Council for the Exploration of the Sea held at Copenhagen on May 23-28, a special session was devoted to submarine light measurements. H. H. Poole gave a brief summary of the results obtained by different workers on the variation of surface loss with weather conditions, pointing out the difficulties involved and stressing the importance of further work on the effect of surface conditions on the angular distribution of submarine daylight.

H. Pettersson described the work of himself and his co-workers on the angular distribution at depths of 5 and $10 \mathrm{~m}$. below a smooth water surface. Their measurements showed that, with the sun shining, the illumination was chiefly concentrated within a comparatively small solid angle round the calculated path of a ray of sunlight, as refracted by a smooth surface, the direction of maximum illumination being slightly nearer the vertical at $10 \mathrm{~m}$. than at $5 \mathrm{~m}$. From these results it is possible to calculate the ratio of the total illumination (as measured by a photometer with a spherical receiving surface) to the vertical illumination (as recorded by a plane photometer with its window horizontal). This is important, since the former is the governing factor in photosynthesis, and the latter is usually measured. The values found for the ratio total/vertical ranged from about 1.5 with the sun at $20^{\circ}$ altitude to 1.35 with diffuse daylight.

M. Graham described measurements of the opacity of the water at 44 stations in the North Sea made by $(a)$ the Lowestoft absorption photometer, $(b)$ measurements of the percentage of daylight at a depth of $10 \mathrm{~m}$., and $(c)$ Seechi's disk. For finding the origin and history of the water masses involved he considers that the use of Seechi's disk has much to recommend it, but that the most promising method is that of Pettersson's transparency meter, in which an artificial light source and a photo-electric cell are used at any required depth.

E. K. Gabrielson and E. Steemann Nielsen reported experiments on the photosynthesis of various diatoms in light of different colours. Their results showed that for a given amount of energy violet-blue light produced about twice as great assimilation of carbon dioxide as either yellow-green or orange-red, the latter spectral regions being about equally efficient.

The special sub-committee on the standardization of photo-cells for daylight measurements held several meetings, and hopes soon to be in a position to undertake this standardization in energy units for different spectral regions. 